\title{
DILATOMETRIC AND METALLOGRAPHIC STUDIES FOR VERIFYING PHASE TRANSFORMATIONS MESOSCALE MODEL
}

\begin{abstract}
The aim of the study was to perform a series of dilatometric experiments, which would be used to further verify and validate a phase transformation mesoscale model based on the cellular automata method. As a result of the study, a CCT graph for steel S355J was developed, which was the basis for further studies of phase transformation kinetics. Subsequently, the study of microstructure using light and scanning microscopy allowed for a qualitative determination of the occurrence of individual structural components in each dilatometric sample. The results of the quantitative analysis of microstructures were used to determine the average primary austenite grain size, as well as to develop a digital material representation. The studies of phase transformation kinetics were carried out using an original computer tool for quantitative dilatometric analysis. Thus, the curves of volume fraction changes of individual structural components as a function of time and temperature were obtained on the basis of data directly from the recorded dilatometric tests. The presented results of quantitative dilatometric analysis with final volume fractions of individual structural components for various cooling rates are a valuable source of data for the direct validation of the mesoscale model of phase transformations.
\end{abstract}

Keywords: dilatometry, metallographic examinations, quantitative dilatometric analysis, phase transformation kinetics, multi-phase steels

\section{BADANIA DYLATOMETRYCZNE I METALOGRAFICZNE SŁUŻĄCE WERYFIKACJI MEZOSKALOWEGO MODELU PRZEMIAN FAZOWYCH}

\begin{abstract}
Celem niniejszej pracy było wykonanie serii eksperymentów dylatometrycznych, które posłuża dalszej weryfikacji $i$ walidacji mezoskalowego modelu przemian fazowych opartego na metodzie automatów komórkowych. W efekcie realizacji pracy opracowano wykres CTPc dla stali z gatunku S355J, który stanowit podstawę do dalszych badań kinetyki przemian fazowych. Kolejno wykonanie badań mikrostruktury $z$ wykorzystaniem mikroskopii świetlnej oraz skaningowej pozwoliło na jakościowe określenie występowania poszczególnych składników strukturalnych w każdej z próbek dylatometrycznych. Wyniki ilościowej analizy mikrostruktur wykorzystano do określania średniej wielkości pierwotnego ziarna austenitu, a także opracowania cyfrowej reprezentacji materiału. Badania kinetyki przemian fazowych zrealizowano za pomoca autorskiego komputerowego narzędzia do ilościowej analizy dylatogramów. Dzięki czemu uzyskano wykresy $z$ przebiegami udziałów objętości poszczególnych składników strukturalnych w funkcji czasu oraz temperatury na podstawie danych pochodzacych bezpośrednio z zarejestrowanych przebiegów dylatometrycznych. Zademonstrowane wyniki ilościowej analizy dylatometrycznej z końcowymi udziałami objętości poszczególnych składników struktury dla różnych szybkości chłodzenia stanowiq cenne źródło danych do bezpośredniej walidacji mezoskalowego modelu przemian fazowych.
\end{abstract}

Stowa kluczowe: dylatometria, badania metalograficzne, ilościowa analiza dylatometryczna, kinetyka przemian fazowych, stale wielofazowe

\section{INTRODUCTION}

Currently, numerical experiments based on advanced physical and mathematical models that allow a satisfactory description of phase transformation kinetics are becoming an increasingly helpful tool in the design and development of new AHSS grades (Advanced High Strength Steels) of the third generation for the automotive industry [1]. The results of numerical simulations carried out in virtual reality based on such models have a value similar or analogous to the results of experiments conducted in reality [2]. The coherence of these results depends on the level of advancement of the developed numerical models and on the knowledge of the conditions of unambiguousness [3]. One of such advanced numerical solutions is the physical mesoscale model of phase transformations enabling the visualisation of the microstructure development during heat treatment of multi-phase steels, which was developed as part of the European project VADPSheets [4]. This model is based on the cellular automata (CA) method in two dimensions and the concept of digital material representation (DMR). 
So far, the proposed CA model has been verified only for several selected multi-phase steels and several specific temperature-time courses [4]. In order to determine its universality, it is necessary to perform a number of numerical simulations and laboratory experiments for various steel grades using different thermal cycles dedicated to the design of multi-phase steels. For this purpose, as part of this study, a series of dilatometric experiments were carried out for the selected steel grade.

The detailed objectives of the study included:

- identification of the dilatometric effect associated with phase transformations (determination of critical temperatures), determination of stereological parameters of selected structural components of the analysed steels by means of the Met-Ilo program [5]

- obtaining images with a digital material representation being the output data for numerical simulations - quantitative analysis of dilatometric courses using an original computer program QDILAM as part of the study [6]

- hardness measurement of selected dilatometric samples after assumed temperature-time cycles.

The realisation of the aforementioned tasks allowed developing a complete set of experimental data, which will be used to further verify and validate the mesoscale model of phase transformations.

\section{MATERIAL, SCOPE AND METHODOLOGY}

\subsection{MATERIAL FOR TESTING}

The chemical composition of the investigated steel S355J is given in Table 1. The input material for the preparation of dilatometer specimens was a $\phi 50 \mathrm{~mm}$ $\times 500 \mathrm{~mm}$ wire with a circular cross-section, originating from a laboratory heat.

\subsection{METHODOLOGY OF DILATOMETRIC STUDIES}

The dilatometric tests were performed on a modern TA Instruments dilatometer DIL 805 A/D/T. During the experiments, the change in the length of the sample was recorded using a linear variable differential transducer (LVDT) and the change of its external diameter was recorded by means of an additional optical measuring system. The measurement of the size of the sample in two dimensions allowed to determine the reproducibility of the experiments, as well as to more accurately determine the temperature of the beginning and the end of phase transformations. The temperature was measured using two or three thermocouples (in the middle and at the ends of the sample), which allowed to assess the influence of the temperature gradient on the length of the sample on the progress of phase transformations.

The samples for dilatometric tests were prepared in the form of standard tubes with an outer diameter of
$4 \mathrm{~mm}$, internal diameter of $2 \mathrm{~mm}$ and length of $10 \mathrm{~mm}$. Typical dilatometric experiments were carried out with twelve cooling rates to plot a CCT graph. All samples were heated at a rate of $10^{\circ} \mathrm{C} / \mathrm{s}$ to austenitising temperature of $930^{\circ} \mathrm{C}$ and annealed for 10 minutes. They were then cooled according to the adopted cooling rates ranging from $10^{\circ} \mathrm{C} / \mathrm{min}$ to about $500^{\circ} \mathrm{C} / \mathrm{s}$. For cooling rates above $20^{\circ} \mathrm{C} / \mathrm{s}$, helium was used as a cooling medium to provide a linear rate of cooling to room temperature. In other cases, nitrogen was used. Experiments were also carried out with temperature-time cycles to determine characteristic temperatures $\left(A_{c 1}, A_{c 3}\right)$. Heating and holding at a given temperature was done in vacuum $<5 \cdot 10^{-4}$ mbar. The temperature deviations measured in the centre of the sample did not exceed the set value of $\pm 1.0^{\circ} \mathrm{C}$.

Based on the analysis of dilatometric diagrams using the tangent to the dilatation curve carried out in accordance with the guidelines included in $[7,8]$, the temperature values of the beginning and end of individual phase transformations were determined. The $A_{c 1}$ and $A_{c 3}$ temperature values were determined from the dilatometric diagram obtained after heating the sample at a rate of $2.5^{\circ} \mathrm{C} / \mathrm{min}$ to $1,000^{\circ} \mathrm{C}$ and then cooling to room temperature at a rate of $10^{\circ} \mathrm{C} / \mathrm{s}$. The parameters of individual temperature-time cycles carried out on the samples from the tested material are presented in the following chapters with test results. Hardness measurement was taken using a Vickers HTM 1839 hardness tester with a load of 98 N. Four imprints were made on the cross-section of the dilatometric samples, and then the average hardness for each sample was calculated.

\subsection{METHODOLOGY OF MICROSTRUCTURAL STUDIES}

Microstructural investigations on etched transverse microsections, in the middle of the length of the dilatometric samples, were carried out using light optical microscopy (LOM) with an OLYMPUS DSX500i optical-digital microscope and scanning electron microscopy (SEM) with an INSPECT F high-resolution scanning microscope. Metallographic microsections for light microscopy were subjected to etching with $1 \%$ nital for $5 \mathrm{~s}$, and for electron microscopy, they were etched on a STRUERS TenuPol-5 electrolytic polishing machine using A8 electrolyte according to the supplier's designations. In case the etching did not give the desired effects, the sample was additionally etched with 1-5\% nital for 5 seconds.

\section{TEST RESULTS AND SUMMARY}

\subsection{RESULTS OF DILATOMETRIC STUDIES}

Fig. 1 presents a diagram of the applied temperature-time courses, according to which dilatometric experiments were carried out. For the thermal cycle with the highest cooling rate (around $526^{\circ} \mathrm{C} / \mathrm{s}$ ), a fully mar-

Table 1. Chemical composition of the investigated steel S355J, [wt \%]

Tabela 1. Skład chemiczny stali w gatunku S355J, [\% wag.]

\begin{tabular}{|c|c|c|c|c|c|c|c|c|c|c|}
\hline Steel grade & $\mathbf{C}$ & $\mathbf{S i}$ & $\mathbf{M n}$ & $\mathbf{C r}$ & $\mathbf{N i}$ & $\mathbf{M o}$ & $\mathbf{C u}$ & $\mathbf{A l}$ & $\mathbf{S}$ & $\mathbf{F}$ \\
\hline S355J & 0.18 & 0.25 & 1.17 & 0.11 & 0.087 & 0.029 & 0.25 & 0.027 & 0.005 & 0.013 \\
\hline
\end{tabular}


tensitic microstructure was obtained at room temperature, which is confirmed by metallographic studies presented in the next section. However, at the remaining cooling rates, ferritic transformation was the first to occur. The full CCT graph is shown in Fig. 2. The ranges of phase transformations visible on it are beneficial from the point of view of the validation of the mesoscale model of these transformations, because in most experiments the ferritic transformation dominates, the modelling of which is used as the main base of the developed physical CA model of phase transformations. Modelling of other phase transformations depends primarily on the progress of ferritic transformation controlled by interface migration, as well as the carbon diffusion process, the kinetics of which are simulated simultaneously.

Due to the higher content of carbon in the S355J steel compared to the previously tested as part of verifying the developed CA model of phase transformations, this steel has the highest hardenability among them. Thus, after conducting the experiment with the highest cooling rate, a martensitic microstructure was obtained, which was used to develop a digital representation of the material, a wider description of which is included in the further part of the paper.

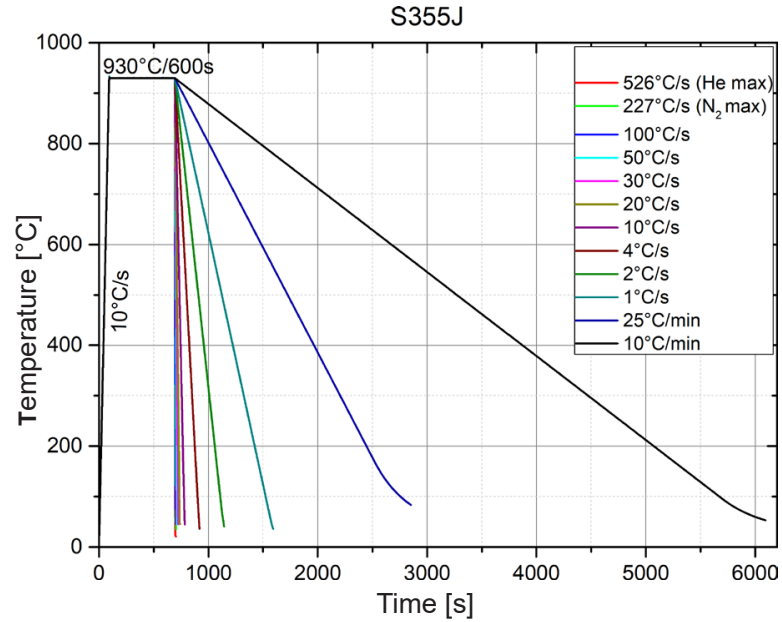

Fig. 1. Temperature-time profiles used during dilatometric experiments

Rys. 1. Profile temperaturowo-czasowe zastosowane w trakcie eksperymentów dylatometrycznych

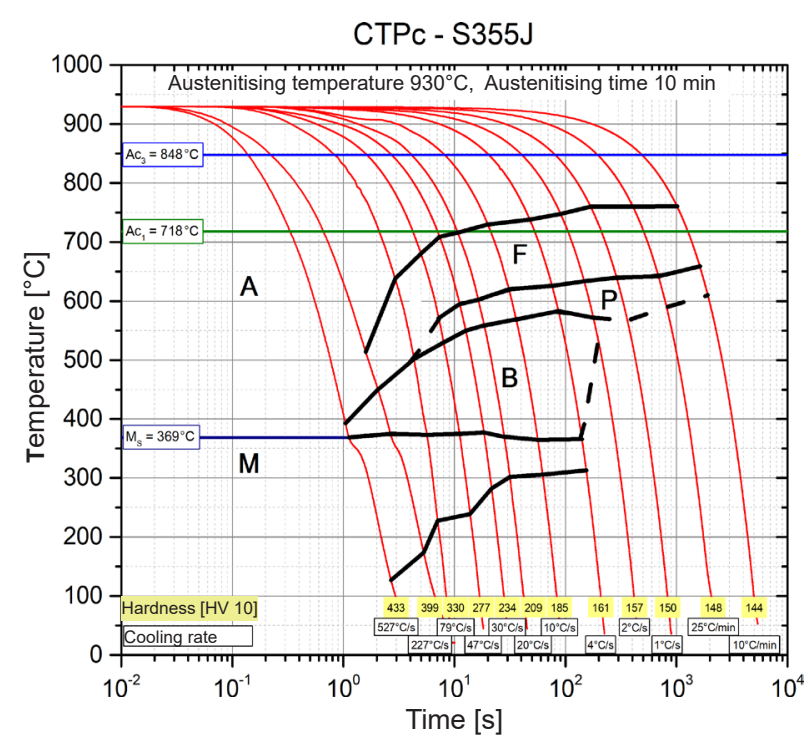

Fig. 2. CCT graph for the S355J steel

Rys. 2. Wykres CTPc dla stali w gatunku S355J

Table 2 presents the values of the beginning and end temperatures of observed phase transformations determined on the basis of dilatometric curves and average hardness (HV10) measurement results of samples from each cooling rate. Such a set of data in a clear tabular form is the basis for plotting a CCT graph, and can also be used to verify the mesoscale CA model of phase transformations.

\subsection{RESULTS OF STRUCTURAL EXAMINATION}

A metallographic examination with a light optical microscope (LOM) and scanning electron microscope (SEM) was carried out on samples after dilatometric experiments. The obtained results were used for the qualitative identification of individual structural components in the development of the CCT graph. Sample microstructure images of dilatometric samples cooled at $20^{\circ} \mathrm{C} / \mathrm{s}$ and $79^{\circ} \mathrm{C} / \mathrm{s}$ are shown in Fig. 3. The coloured images from the light microscope show ferrite grains in the form of white polygons, while the dark grey areas are pearlite. The remaining structural components

Table 2. Comparison of dilatometric analysis results for different cooling rates

Tabela 2. Zestawienie wyników analizy dylatogramów dla różnych szybkości chłodzenia

\begin{tabular}{|c|c|c|c|c|c|c|c|c|c|}
\hline \multirow{2}{*}{ Cooling rate } & \multicolumn{8}{|c|}{ Critical temperature of phase transformations } & \multirow{2}{*}{ Hardness } \\
\hline & $M_{f}$ & $M_{s}$ & $\boldsymbol{B}_{f}$ & $\boldsymbol{B}_{\boldsymbol{s}}$ & $\boldsymbol{P}_{f}$ & $\boldsymbol{P}_{s}$ & $\boldsymbol{F}_{f}$ & $\boldsymbol{F}_{s}$ & \\
\hline$\left[{ }^{\circ} \mathbf{C} / \mathbf{s}\right]$ & {$\left[{ }^{\circ} \mathbf{C}\right]$} & {$\left[{ }^{\circ} \mathbf{C}\right]$} & {$\left[{ }^{\circ} \mathbf{C}\right]$} & {$\left[{ }^{\circ} \mathbf{C}\right]$} & {$\left[{ }^{\circ} \mathbf{C}\right]$} & {$\left[{ }^{\circ} \mathbf{C}\right]$} & {$\left[{ }^{\circ} \mathbf{C}\right]$} & {$\left[{ }^{\circ} \mathbf{C}\right]$} & [HV10] \\
\hline 526 & 127 & 369 & 369 & 393 & - & - & - & - & 433 \\
\hline 227 & 174 & 375 & 375 & 450 & - & - & 450 & 514 & 399 \\
\hline 79.2 & 228 & 373 & 373 & 502 & - & - & 502 & 638 & 330 \\
\hline 46.8 & 239 & 375 & 375 & 530 & 530 & 571 & 571 & 680 & 277 \\
\hline 30 & 282 & 377 & 377 & 550 & 550 & 595 & 595 & 709 & 234 \\
\hline 20 & 302 & 370 & 370 & 559 & 559 & 602 & 602 & 716 & 209 \\
\hline 10 & 306 & 365 & 365 & 569 & 569 & 620 & 620 & 730 & 185 \\
\hline 4 & 313 & 366 & 366 & 583 & 583 & 626 & 626 & 738 & 161 \\
\hline 2 & - & - & 535 & 572 & 572 & 634 & 634 & 748 & 157 \\
\hline 1 & - & - & - & - & 567 & 640 & 640 & 760 & 150 \\
\hline 0.41667 & - & - & - & - & 590 & 642 & 642 & 760 & 148 \\
\hline 0.16667 & - & - & - & - & 610 & 659 & 659 & 761 & 144 \\
\hline
\end{tabular}


(bainite, martensite, residual austenite) are much easier to recognise in the microstructure images from the scanning microscope. Areas in the form of thin sheaves of laths or plates with small precipitates of irregularly shaped carbides occurring inside or between them can be interpreted as bainite. In turn, martensite on SEM images has a form of light grey packets, which can be treated as single grains composed of parallel laths forming sheaves. Residual austenite remaining in the structure assumes irregular shapes in light grey colour and can be located on the edges of martensite packets, which together with them forms martensite and austenite islands (MA).

The qualitative assessment of the occurrence and content of ferrite and pearlite was made on the basis of four images from LOM for samples from each cooling rate, while eight images from SEM were used to make a qualitative assessment of the occurrence and content of bainite and martensite. In the microstructure images for the sample cooled at $20^{\circ} \mathrm{C} / \mathrm{s}$, qualitatively it can be estimated that about $50 \%$ of the volume is occupied by ferrite. The surface fracture of pearlite and bainite is at a similar level, and amounts to about $20 \%$ each. The rest is martensite with residual austenite, which in total is about $10 \%$. Micrographs of the dilatometric sample cooled at $79^{\circ} \mathrm{C} / \mathrm{s}$ show that about $30 \%$ of the volume is ferrite. It was found that pearlite does not occur in the examined microstructures. The surface fracture of bainite and martensite is at a similar level, and amounts to about $30 \%$ each.

Cooling at $526^{\circ} \mathrm{C} / \mathrm{s}$ allowed to obtain a martensitic structure in the tested samples. As it is known, based on the images of such a microstructure, the austenite grain boundaries present in the sample immediately before the martensitic transformation can be reconstructed. Therefore, these images were used to determine these grain sizes with the Met-Ilo program [5]. Sample images of martensitic structure along with manually marked austenite grain boundaries (red lines) are shown in Fig. 4, while the comparison of
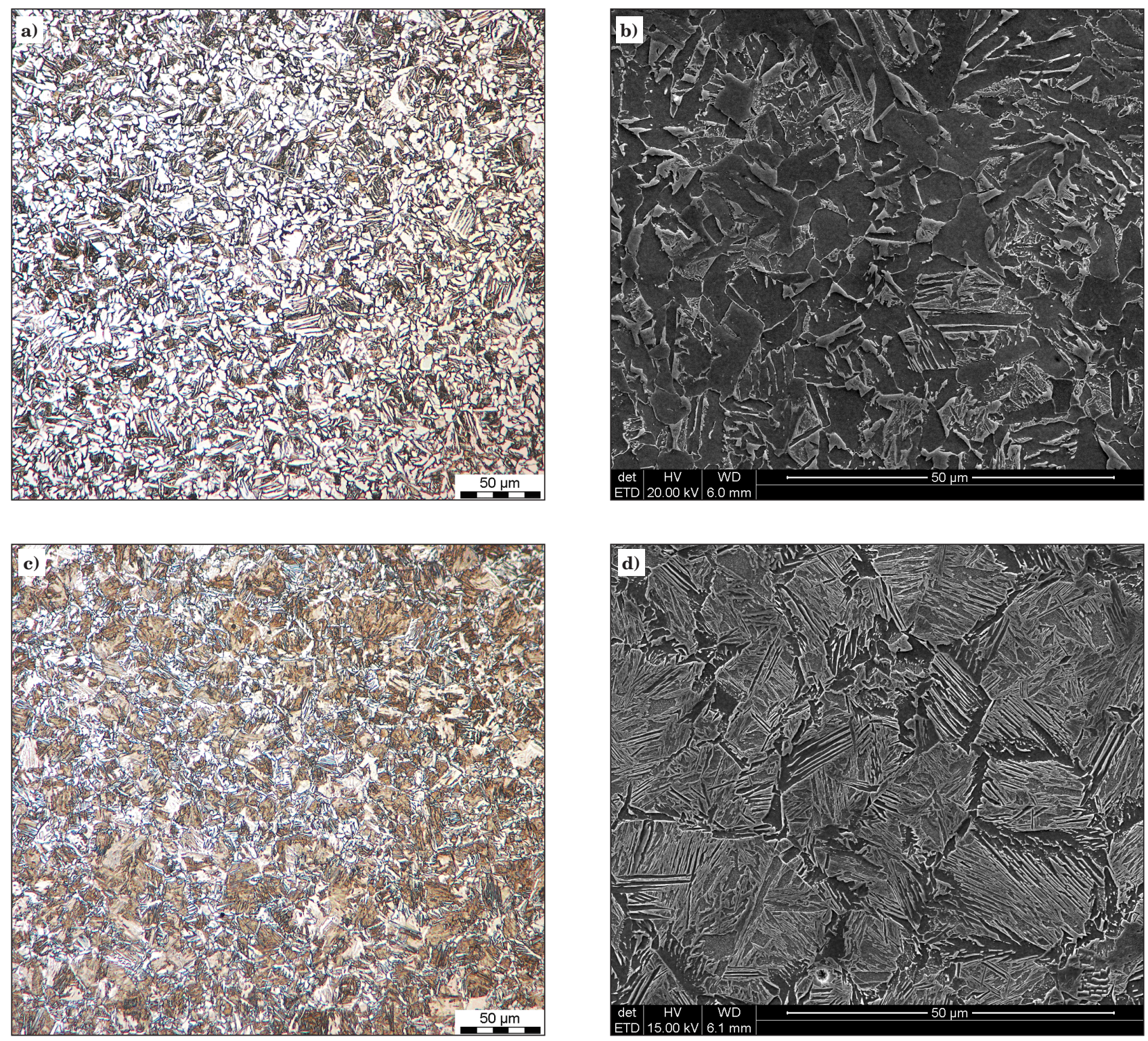

Fig. 3. Sample metallographic images obtained using LOM (a, c) and SEM (b, d) for dilatometric samples cooled at the following rates: $20^{\circ} \mathrm{C} / \mathrm{s}$ (a) and (b), $79^{\circ} \mathrm{C} / \mathrm{s}$ (c) and (d)

Rys. 3. Przykładowe obrazy mikrostruktury uzyskane za pomocą LOM (a, c) oraz SEM (b, d) dla próbek dylatometrycznych chłodzonych z szybkością: $20^{\circ} \mathrm{C} / \mathrm{s}(\mathrm{a})$ i (b), $79^{\circ} \mathrm{C} / \mathrm{s}$ (c) i (d) 
values of the average size of primary austenite grain, determined based on nine SEM images of the dilatometric sample cooled at the rate of $526^{\circ} \mathrm{C} / \mathrm{s}$ is shown in Table 3. The average diameter of austenite grain was determined using two calculation methods, hydraulic diameter and Feret diameter. More information on how to determine these parameters can be found in [9]. Austenite grain boundaries marked in Fig. 4 may be used to develop a digital material representation according to the algorithm presented in [10]. The solution consists in the conversion of binary microstructure images, with austenite grain boundaries outlined with the Met-Ilo program [5], to a cellular automata grid. As a result, micrographs corresponding to the original austenite microstructure at a temperature of $930^{\circ} \mathrm{C}$ in the form of a digital material representation are introduced to simulation in the CA model, as shown in Fig. 5. Thus, it is possible to carry out reliable numerical simulations of mesoscale phase transformations, using realistic initial conditions on the CA grid, in ac-
Table 3. Comparison of the calculated values of the average primary austenite grain size according to two methods based on data from the experiment (002NDH171302) at a cooling rate of $526^{\circ} \mathrm{C} / \mathrm{s}$

Tabela 3. Zestawienie obliczonych wartości średniej wielkości pierwotnego ziarna austenitu według dwóch metod na podstawie danych $\mathrm{z}$ eksperymentu (002NDH171302) z szybkością chłodzenia $526^{\circ} \mathrm{C} / \mathrm{s}$

\begin{tabular}{|l|c|c|c|c|}
\hline Method & $\begin{array}{c}\text { Average } \\
\text { diameter } \\
{[\boldsymbol{\mu \mathrm { m } ]}}\end{array}$ & $\begin{array}{c}\text { Smallest } \\
\mathbf{d i a m e t e r} \\
{[\boldsymbol{\mu} \mathrm{m}]}\end{array}$ & $\begin{array}{c}\text { Largest } \\
\mathbf{d i a m e t e r} \\
{[\boldsymbol{\mu \mathrm { m } ]}]}\end{array}$ & $\begin{array}{c}\text { Number } \\
\text { of } \\
\text { grains }\end{array}$ \\
\hline Equivalent & 11.3 & 1.3 & 21.8 & 105 \\
\hline Feret & 13.7 & 2.6 & 27.5 & 105 \\
\hline
\end{tabular}

cordance with the cooling diagrams shown in Fig. 1. Next, the obtained results of CA simulations, in the form of virtual microstructures and kinetics of individual phase transformations, can be directly compared with experimental data.
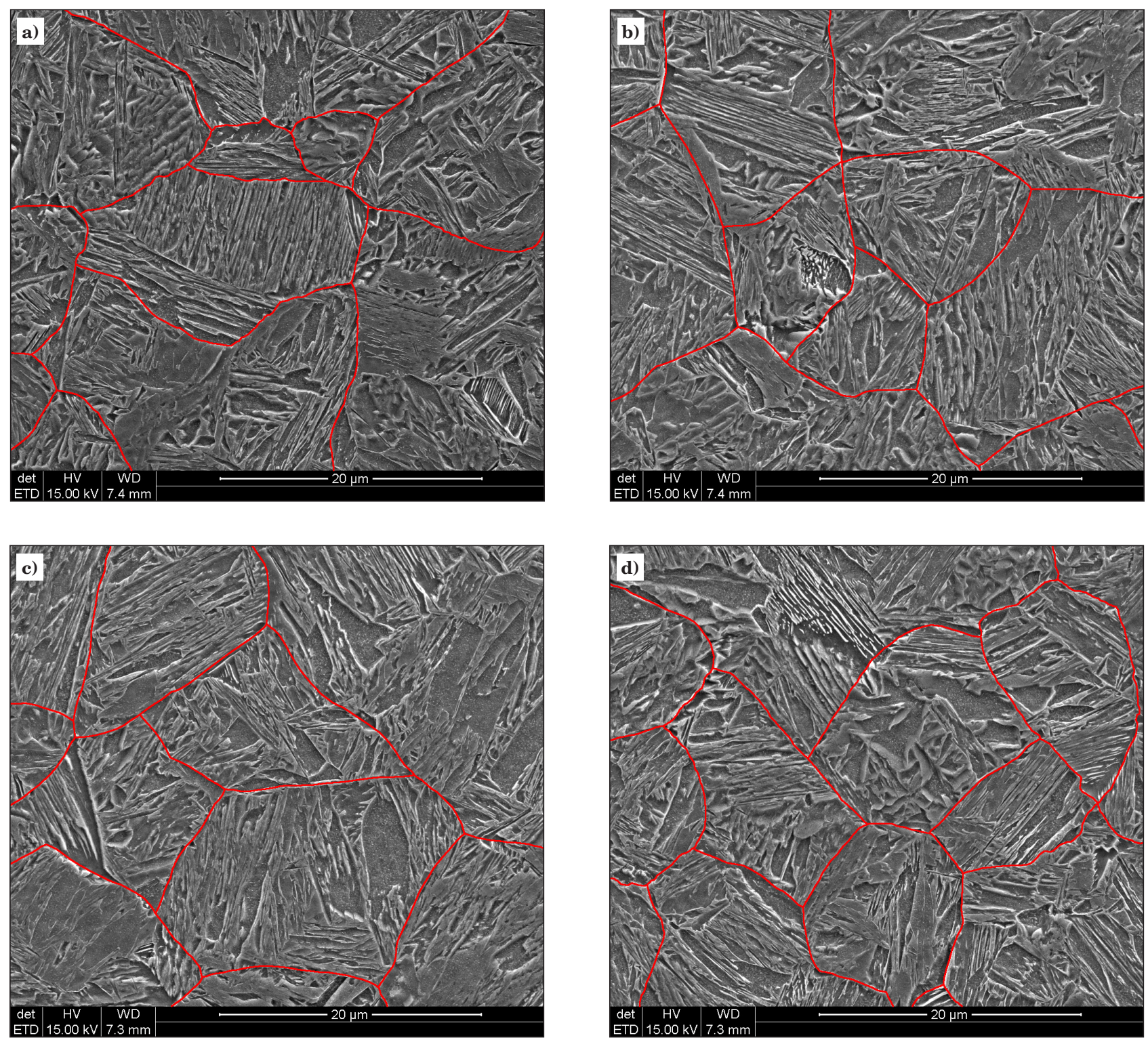

Fig. 4. Sample micrographs of the microstructure of a dilatometric sample (002NDH171302) after cooling with a maximum rate $\left(526^{\circ} \mathrm{C} / \mathrm{s}\right)$ registered using SEM along with marked primary austenite boundaries

Rys. 4. Przykładowe obrazy mikrostruktury próbki dylatometryeznej (002NDH171302) po chłodzeniu z maksymalną szybkością $\left(526^{\circ} \mathrm{C} / \mathrm{s}\right)$ zarejestrowane za pomocą SEM wraz z zaznaczonymi pierwotnymi granicami austenitu 

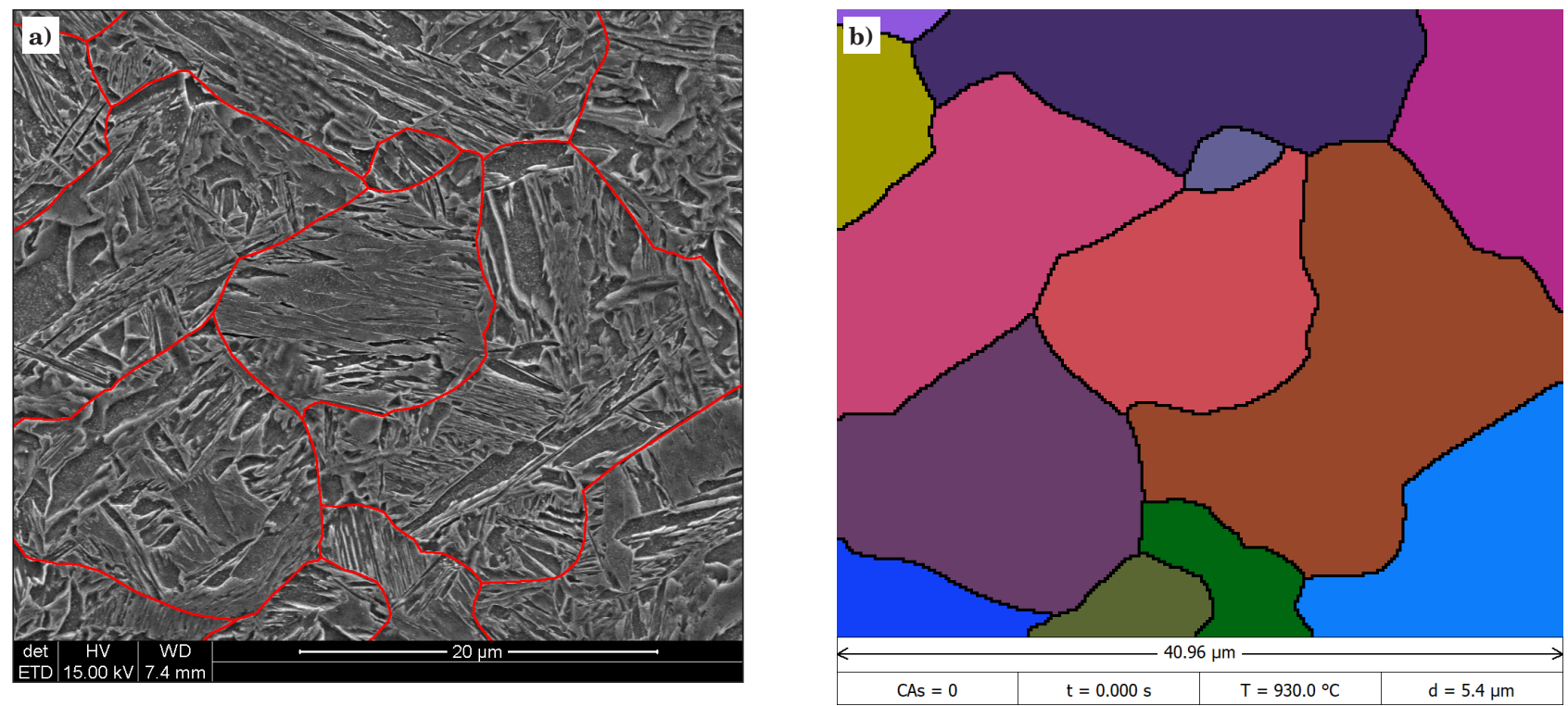

Fig. 5. Example of conversion of a real martensitic microstructure: (a) with revealed primary austenite grain boundaries to a digital material representation, (b) using a cellular automata grid

Rys. 5. Przykład konwersji rzeczywistej mikrostruktury martenzytycznej: (a) z ujawnionymi pierwotnymi granicami ziaren austenitu na cyfrową reprezentację materiału, (b) za pomocą siatki automatów komórkowych

\subsection{RESULTS OF QUANTITATIVE DILATOMETRIC ANALYSIS}

An instance of results of quantitative dilatometric analysis of a sample cooled at $20^{\circ} \mathrm{C} / \mathrm{s}$ is presented in

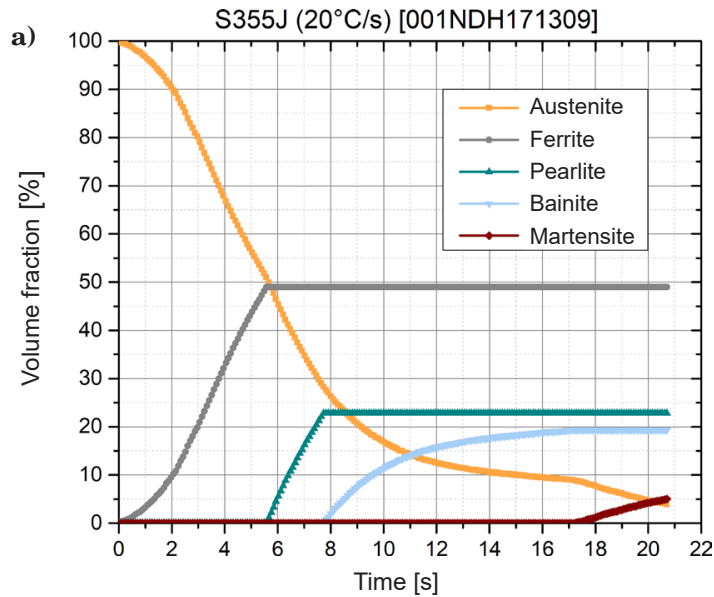

Fe-Fe3C equilibrium system section - steel S355J

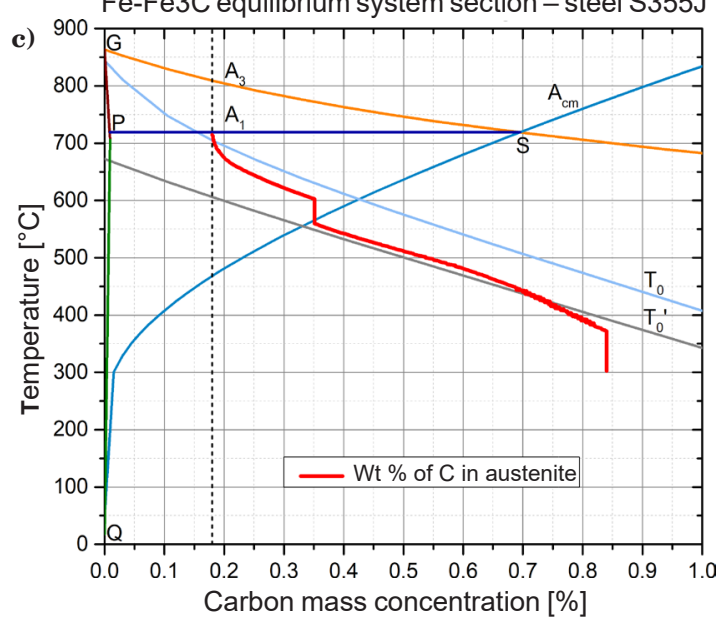

Fig. 6. The first two graphs (a and b) show the courses of the volume fraction of individual structural components as a function of time and temperature. Fig. 6c contains a fragment of the $\mathrm{Fe}-\mathrm{Fe} 3 \mathrm{C}$ phase equilibrium

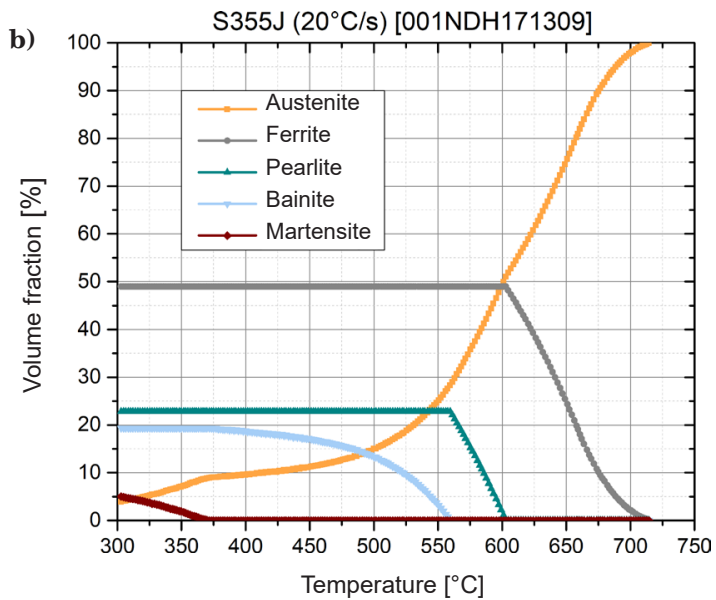

S355J $\left(20^{\circ} \mathrm{C} / \mathrm{s}\right)[001 \mathrm{NDH} 171309]$

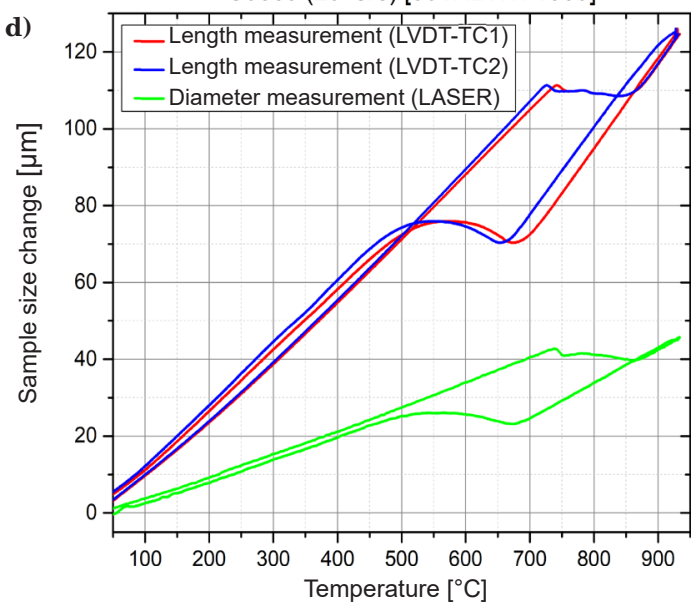

Fig. 6. Results of quantitative dilatometric analysis of a sample cooled at $20^{\circ} \mathrm{C} / \mathrm{s}$. Details in the text Rys. 6. Wyniki ilościowej analizy dylatometrycznej próbki chłodzonej z szybkością $20^{\circ} \mathrm{C} / \mathrm{s}$. Szczegóły w tekście 
Table 4. Results of quantitative dilatometric analysis for different cooling rates

Tabela 4. Wynik ilościowej analizy dylatometrycznej dla różnych szybkości chłodzenia

\begin{tabular}{|c|c|c|c|c|c|}
\hline \multirow{2}{*}{$\begin{array}{c}\text { Cooling rate } \\
{\left[{ }^{\circ} \mathbf{C} / \mathbf{s}\right]}\end{array}$} & \multicolumn{5}{|c|}{ Volume fraction of structural components } \\
\cline { 2 - 6 } & $\begin{array}{c}\text { Austenite } \\
{[\%]}\end{array}$ & $\begin{array}{c}\text { Martensite } \\
{[\%]}\end{array}$ & $\begin{array}{c}\text { Bainite } \\
{[\%]}\end{array}$ & $\begin{array}{c}\text { Pearlite } \\
{[\%]}\end{array}$ & $\begin{array}{c}\text { Ferrite } \\
{[\%]}\end{array}$ \\
\hline 526 & - & 94.3 & 5.7 & - & - \\
\hline 227 & - & 57.3 & 26.2 & - & 16.5 \\
\hline 79.2 & - & 33.0 & 27.0 & - & 39.9 \\
\hline 46.8 & - & 19.2 & 25.6 & 18.0 & 37.2 \\
\hline 30 & - & 10.5 & 21.6 & 24.8 & 43.1 \\
\hline 20 & 3.9 & 5.0 & 19.4 & 22.8 & 49.0 \\
\hline 1 & 0.9 & - & - & 28.5 & 70.6 \\
\hline 0.41667 & - & - & - & 27.3 & 72.7 \\
\hline 0.16667 & - & - & - & 30.5 & 69.5 \\
\hline
\end{tabular}

system along with the course of changes in the average carbon concentration in austenite during phase transformations. The quantitative analysis was carried out with an original software QDILAM [6] based on the dilatometric diagram (Fig. 6.d) showing the change of linear displacements on the length of the sample (LVDT) as a function of temperature measured by means of the first thermocouple fixed at the centre of the sample (directive, TC1). The remaining courses concern linear displacements on the sample length (LVDT) as a function of temperature recorded with a thermocouple fixed on the edge of the sample (control, TC2) and changes in transverse dimensions of the sample's external diameter by means of an optical measuring system (laser). These curves support the analysis when determining the temperature value of the beginning and end of phase transformations.

The quantitative analysis of all dilatometric diagrams obtained during the study was carried out in the same way. The results of quantitative dilatometric analysis are a valuable source of information on the kinetics of individual phase transformations obtained directly from experimental data, which in effect should enable an accurate verification of mesoscale modelling of phase transformations using the cellular automata method. The comparison of the final volume fraction values of individual structural components for all cooling rates determined using QDILAM is given in Table 4 . These data can be used to directly validate the results of numerical simulations of phase transformations carried out in mesoscale using the CA model.

\section{SUMMARY OF RESULTS AND CONCLUSIONS}

The series of dilatometric experiments carried out with a DIL $805 \mathrm{~A} / \mathrm{D} / \mathrm{T}$ dilatometer enabled the plotting of a CCT graph for the S355J steel, which formed the basis for further studies of phase transformation kinetics. The specific morphological features of the structural components found in the tested samples revealed in the microstructural images registered with the use of light microscopy and SEM allowed for the unambiguous identification of these components.

The average size of primary austenite grain was determined based on the quantitative metallographic analysis of the martensitic microstructure obtained in the sample cooled at $526^{\circ} \mathrm{C} / \mathrm{s}$ with manually outlined austenite grain boundaries. These outlines were also used to develop a digital material representation according to the algorithm presented in [10]. Thus, it is possible to apply realistic initial conditions on the CA grid in the form of digital austenite microstructures to carry out reliable numerical simulations of phase transformations in mesoscale.

The studies of phase transformation kinetics were carried out using a computer tool for quantitative dilatometric analysis, i.e., the original program QDILAM [6]. This allowed to obtain graphs of changes in the volume fraction of individual structural components as a function of temperature and time on the basis of the data that come directly from the registered dilatometric courses. In addition, the QDILAM software enables the presentation of analysis results in the form of a graph of changes in average carbon concentration in austenite during cooling, which is a valuable supplement to the phase transformation kinetics research.

The test results developed as part of this paper in the form of an appropriately formatted dataset (e.g. Table 2 and 4) will be used to validate the mesoscale model of phase transformations, which was implemented as part of the European project VADPSheets [4]. In addition, the obtained results will allow to authenticate and verify mesoscale modelling of phase transformations using the cellular automata method.

\section{REFERENCES}

[1] G. Gorecki, L. Madej, M. Pietrzyk. Computer Software Tool for the Design of Optimal Thermal Cycles in the Continuous Annealing of DP Steels. Journal of Machine Engineering, 2014, (14), p. 74-83.

[2] W. Kapturkiewicz, E. Fraś, A.A. Burbelko. Why is the computer modelling needed in casting? Przeglad Odlewnictwa, 2005, (1), p. 15-23.
[3] W. Kapturkiewicz. Eksperyment numeryczny jako metoda wyjaśnienia mechanizmu procesu. Zeszyty Naukowe. Mechanika. Politechnika Opolska, 1999, (59), p. 181-190.

[4] R. Kuziak, M. Pietrzyk, L. Madej, C. Halder, W. Madej, L. Rauch, R. Szyndler, Z. Gronostajski, G. Smyk, J.Ch. Hell, T. Iung, N. Kwiaton, J.-L. Collet, G. Lannoo, J. Opara, W. Zalecki, A. Mazur, K. Radwański. Property oriented design of 
hard constituent hardness and morphology in continuous ly annealed/galvanised DP sheets. RFSR-CT-2011-00014. (2011-2014).

[5] J. Szala. Met-Ilo v12.1 - instrukcja obsługi programu. Katowice, 2009.

[6] J. Opara, A. Wrożyna. Development and validation of a quantitative dilatometric analysis model of austenite decomposition into ferrite and pearlite. Prace Instytutu Metalurgii Żela$z a, 2015$, (4), p. 24-32.

[7] Stahl-Eisen-Prüfblatt (SEP) 1681. Guidelines for preparation, execution and evaluation of dilatometric transformation tests on iron alloys. 2nd ed. (1997).
[8] ASTM. A1033. Standard Practice for Quantitative Measurement and Reporting of Hypoeutectoid Carbon and Low-Alloy Steel Phase Transformations, ASTM. Committee A01 on Steel, Stainless Steel and Related Alloys, March 2004.

[9] L. Wojnar, K.J. Kurzydłowski, J. Szala. Practice of image analysis. Kraków: Polskie Towarzystwo Stereologiczne, 2002.

[10] J. Opara, A. Wrożyna. Zastosowanie metody automatów komórkowych do opracowania cyfrowej reprezentacji wybranych cech mikrostruktury w oparciu o obrazy binarne jej składników. Prace Instytutu Metalurgii Żelaza, 2013, (4), p. 2-7. 